\title{
Education of Life Proficiency in History Learning
}

\section{Muadz Assidiqi, Hermanu, Sariyatun}

Universitas Sebelas Maret

muadzassidiqi14@gmail.com

\section{Article History}

accepted 1/09/2020

approved 4/10/2020

published 1/12/2020

\begin{abstract}
The twenty-first century continues to experience a breakdown in the foundations of society which causes new and worrisome things. The emergence of a pandemic in this century has a consequence that has caused various problems, especially in the field of education. The development of community needs for education services, especially at the senior high school level (SMA) is not following the improvement of the quality of human resources with life skills. This happens because educational services have not been able to carry out face-to-face learning completely. The implementation of distance learning $(P J J)$, the use of online learning technology, re-orientation of the curriculum, and improving the skills of educators are policies that are taken to overcome these problems. This study uses a literature review method that aims to critically examine ideas, findings, and knowledge of life skills education to analyze and solve educational problems during the Pademi era, especially in history learning.
\end{abstract}

Keywords: 21st century, pandemic, distance learning, life skills education, history learning

\begin{abstract}
Abstrak
Abad dua puluh satu terus mengalami perombakan dalam fondasi masyarakat yang menyebabkan hal baru dan mengkhawatirkan. Munculnya pandemi di abad ini memiliki suatu konsekuensi yang menimbulkan berbagai permasalahan khususnya dalam bidang pendidikan. Perkembangan kebutuhan masyarakat akan layanan pendidikan khususnya pada tingkat Sekolah Menengah Atas (SMA) tidak sesuai dengan peningkatan kualitas sumber daya manusia yang memiliki kecakapan hidup. Hal ini terjadi karena layanan pendidikan belum mampu melaksanakan pembelajaran tatap muka seutuhnya. Penyelenggaraan pembelajaran jarak jauh (PJJ), penggunaan teknologi pembelajaran daring, re-orientasi kurikulum dan peningkatan keterampilan tenaga pendidik menjadi kebijakan yang ditempuh untuk mengatasi permasalahan tersebut. Penelitian ini menggunakan metode literatur review yang bertujuan untuk mengkaji secara kritis gagasan, temuan dan pengetahuan mengenai pendidikan kecakapan hidup (life skills) untuk menganalisis dan memecahkan permasalahan pendidikan di masa pademi khususnya dalam pembelajaran sejarah.
\end{abstract}

Kata Kunci: Abad 21, pandemi, pembelajaran jarak jauh, pendidikan kecakapan hidup (life skills), pembelajaran sejarah

\begin{tabular}{ll}
\hline Social, Humanities, and Education Studies (SHEs): Conference Series & p-ISSN 2620-9284 \\
https://jurnal.uns.ac.id/shes & e-ISSN 2620-9292
\end{tabular}




\section{PENDAHULUAN}

Pendidikan di Indonesia secara garis besar memiliki satu tujuan utama: mempersiapkan siswa untuk menjadi anggota masyarakat yang independen dan bertanggung jawab. Pendidikan memberikan peluang dalam konteks kehidupan nyata untuk mendorong perkembangan perilaku adaptif dan keterampilan tingkat tinggi seperti penetapan tujuan, pengambilan keputusan, pemecahan masalah, refleksi dan perencanaan (Duff, et al., 2019: 1). Pndidikan seharusnya dihadapkan pada lingkungan belajar yang dapat menghasilkan kepercayaan diri manusia untuk secara independen dapat meningkatkan dan menghasilkan pemikiran kritis, efikasi diri dan penentuan nasib sendiri bagi kehidupannya mendatang (McPherson, Rudzik, Kingsnorth, et al., 2018).

Menteri pendidikan sebagai pemangku kepentingan dalam bidang pendidikan selalu mengubah standar kurikulum untuk beradaptasi dengan setiap perubahan dan perkembangan yang berada dimasyarakat. Ornstein, A. C., \& Hunkins, F.P. (2016:151171) mengatakan kurikulum memiliki keterkaitan dengan lingkungan masyarakat. Perubahan lingkungan masyarakat masa pandemi berdampak pada perubahan kurikulum. Kecakapan hidup menjadi satu hal yang konstan ditengah perubahan kurikulum yang tetapkan. Pendidikan kecakapan hidup kurang optimal dilingkungan sekolah menengah atas karena sekolah terlalu obsesif berfokus pada standar pertemuan, mengajar dari kurikulum bernaskah, dan memenuhi standar tes. Sehingga, pelaksanaannya siswa cenderung menimbun informasi atas permintaan guru hingga memuntahkannya tanpa melewati proses berpikir, merencanakan, dan bertindak secara mandiri.

Pendidikan kecakapan hidup dilingkungan siswa sekolah menengah atas juga kurang mendapatkan perhatian dibanding pendidikan kecakapan hidup dilingkungan akademisi. Meskipun, struktur sekolah terus berkembang namun kenyataannya siswa kurang mendapat dukungan dari sekolah untuk meningkatkan kecakapan hidup yang diperlukan untuk berkembang setelah lulus. Kecakapan hidup diartikan sebagai kemampuan psikososial untuk perilaku adaptif dan positif untuk memungkinkan individu untuk secara efektif mengatasi permasalahan dan tantangan melalui berbagai keterampilan seperti komunikasi, ketegasan, kesadaran diri, pengambilan keputusan, pemecahan masalah, pemikiran kritis dan kreatif untuk melindungi mereka dari penyalahgunaan dan eksploitasi (UNICEF, 2015; WHO, 1993). Pentingnya siswa secara khusus untuk menggunakan dan memelihara kecakapan hidup yang diperoleh dari lingkungan sekolah maupun lingkungan keluarga bahkan masyarakat untuk mengambil bagian dalam kehidupan sosial masyarakat khususnya dalam dunia kerja. Rateau, Kaufman, dan Cletzer, (2015) menyatakan bahwa dunia kerja sangat kompetitif dan cepat berubah dimana pendidikan kecakapan hidup semakin penting mengingat lulusan saat ini sering pergi ke tempat kerja tanpa persiapan untuk memenuhi standard kerja yang berkembang dalam suatu masyarakat. Lingkungan masyarakat selalu memunculkan permintaan akan keterampilan yang berbeda, yang memungkinkan seseorang yang berada didalamnya untuk menjadi fleksibel dan mudah beradaptasi dalam peran dan karir yang berbeda (Kansaart et al., 2018: 2).

Penelitian yang dilakukan (Yadav \& Iqbal, 2009) menunjukkan hal yang positif dan negatif. Secara positif pendidikan memberikan perubahan pada sikap, pikiran, dan perilaku siswa. Secara negatif, siswa sekolah menengah atas kurang menyadarinya konsep yang perlu mereka pahami dan manfaatkan untuk memperoleh kemandirian belajar. Rendahnya kecakapan hidup mengakibatkan siswa merasakan frustrasi atas kurangnya pemahaman mereka terkait dengan permasalahan kehidupan mereka seharihari. Siswa mengungkapkan kebutuhannya, namun tidak memiliki pemahaman tentang apa atau bagaimana mereka perlu dilatih dan dikembangkan. Siswa mulai mempertanyakan mengapa kecakapan hidup kurang diajarkan di kelas sekolah menengah atas. Mengintegrasikan pelatihan kecakapan hidup melalui pendidikan akan membantu siswa untuk mengatasi berbagai kesulitan dalam hidup (Prajapati, B. Sharma, \& D. Sharma, 2017: 1). 
Selain itu, pendidikan kecakapan hidup memberikan motivasi, meningkatkan keterampilan sosial dan manajemen diri untuk berbagai pengalaman hidup, seperti membahas dan memasukkan kebutuhan dan minat siswa. . Perencanaan standar yang tepat sangat diperlukan untuk mempertimbangkan penerapan kecakapan hidup ke dalam kehidupan sehari-hari untuk menanggapi minat, keinginan, dan kebutuhan siswa. Apalagi analisis standar pendidikan sejarah menunjukkan keterampilan hidup tertanam di dalamnya. Misalnya, siswa harus memulai dan berpartisipasi secara efektif dalam berbagai diskusi kolaboratif (satu lawan satu, dalam kelompok, dan dipimpin guru) dengan topik, masalah, membangun ide dari orang

lain dan mengekspresikan kemampuannya dengan jelas dan persuasif.

Standar tersebut memberikan harapan pada siswa sekolah menengah atas untuk menguasai keterampilannya dengan memprioritaskan, keterampilan sosial yang tepat, dan kolaborasi.. Hal ini menjadi sebuah pertanyaan, dengan cara apa siswa dapat menerapkan keterampilan yang didapat di sekolah dalam kehidupan realita. Penulisan ini diharapkan dapat digunakan sebagai masukan bagi penyusunan standar yang diperlukan untuk mempersiapkan siswa memperoleh pendidikan kecakapan hidup khususnya dalam pembelajaran sejarah.

\section{METODE}

Metode penelitian ini menggunakan metode literature review. Menurut Creswell (2014:27-28) literatur review merupakan analisis literatur yang dilakukan pada topik penelitian serta memiliki tujuan untuk memberikan informasi kepada pembaca mengenai hasil-hasil penelitian sebelumnya yang memiliki keterkaitan dengan penelitian yang dilakukan saat ini, serta menghubungkan penelitian dengan literatur-literatur yang ada, dan mengisi celah-celah dalam penelitian-penelitian sebelumnya.

\section{HASIL DAN PEMBAHASAN}

Hasil penelitian tentang pendidikan kecakapan hidup dalam pembelajaran sejarah diuraikan menjadi lima bagian, yaitu tahap perencanaan, pelaksanaan, kendala-kendala, upaya mengatasi kendala dan apresiasi serta persepsi peserta didik.

1. Perencanaan Pendidikan Kecakapan Hidup dalam Pembelajaran Sejarah Pendidikan kecakapan hidup umumnya direncanakan untuk mencegah berbagai tantangan kecakapan hidup yang dihadapi siswa seperti merokok, alkohol, penggunaan narkoba, pelecehan seksual, putus sekolah dan kehamilan diluar nikah (Botvin, Griffin, Diaz, \& Ifill-Williams, 2001; CampbellHeider, Tuttle, \& Knapp, 2009; Givaudan, Leenen, Van De Vijver, Poortinga, \& Pick, 2008; MacKillop, Ryabchenko, \& Lisman, 2006; Martin, Nelson, \& Lynch, 2013; Menrath et al., 2012; Uwazi dalam Budoya. dkk, 2019: 382). Perencanaan pendidikaan kecakapan hidup dalam pembelajaran sejarah di masa pandemi dapat dilakukan dengan penyusunan kurikulum merdeka belajar dengan berawal dari penyusunan program tahunan, program silabus, RPP (rencana pelaksanaan pembelajaran) yang memuat indikator ketercapaian pembelajaran, pendekatan pembelajaran, standar kompetensi (SK) dan kompetensi dasar (KD) yang disusun secara merdeka atau mandiri sesuai dengan kebutuhan dan masalah masing-masing guru sejarah dengan dan tetap mengacupada Permendiknas No. 22 tahun 2006.

Guru dapat merencanakan pendekatan yang tepat untuk mengajarkan kecakapan hidup salah satunya melalui pendekatan infus. Pendekatan infusi bertujuan untuk mengajari siswa bagaimana menerjemahkan informasi dan konsep belajar siswa di sekolah ke dalam kehidupan sehari-hari mereka.

Dengan demikian, muatan kecakapan hidup dapat ditanamkan ke dalam 
mata pelajaran yang tercantum di kurikulum sekolah dengan metode penyampaian yang inovatif (Smith et al., 2004 dalam Nasheeda et al., 2018: 3).

2. Pelaksanaan Pendidikan Kecakapan Hidup dalam Pembelajaran Sejarah

Pendidikan kecapakapan hidup menurut (WHO, 1993; Trilling \& Fadel 2009: 49; Danish et al, (2014); Jedaman et al., 2018: 8) dalam pelaksanaannya mengacu pada 5 keterampilan utama sebagai berikut:

a. Keterampilan komunikasi merupakan keterampilan tingkat dasar dalam pendidikan kecakapan hidup (WHO, 1993). Keterampilan komunikasi dalam pembelajaran sejarah, merupakan kemampuan menerima dan mengirim pesan melalui bahasa, pengetahuan, pemahaman, perasaan serta pandangan tentang diri siswa untuk bertukar informasi dengan siswa lain yang dilaksanakan melalui diskusi dalam proses pembelajaran. Selain itu, keterampilan komunikasi yang berkaca pada sejarah akan memudahkan siswa memahami perkembangan sosial masyarakat. Pembelajaran sejarah mengajarkan siswa untuk saling menghargai setiap keberagaman serta memahami pentingnya bahasa sebagai keterampilan yang akan berguna bagi kelangsungan hidupnya saat berada di daerah yang berbeda bahasa dengan lingkungan asalnya. Beberapa peneliti setuju dengan menaruh perhatian pada keterampilan berkomunikasi dan berkolaborasi sebagai penetapan tujuan kecakapan hidup, sebagai langkah kompeten seseorang (siswa) secara sosial untuk dapat menggunakan pengalaman sosial dalam memenuhi tujuan dan kebutuhan mereka, sambil memahami kebutuhan dan tujuan orang lain (Groeben, Perren, Stadelmann, \& Klitzing, 2011, seperti dikutip oleh Garrote, 2017).

b. Keterampilan berpikir dalam pembelajaran sejarah, berawal dari memahami hingga menganalisis suatu peristiwa yang bertema isu-isu kontroversial nantinya dapat membentuk keterampilan berpikir sintetik, berpikir kreatif, berpikir kritis dan berpikir sistematis. Sehingga, pemikiran siswa nantinya dapat mengarah pada penciptaan pengetahuan atau berkreasi.

c. Keterampilan memecahkan masalah dalam pembelajaran sejarah, berdasarkan pada penalaran, memahami moral yang berlaku di masyarakat setempat dan informasi yang berkembang, Siswa harus memahami setiap hubungan dan peristiwa dalam masyarakat, serta menjadikan peristiwa sejarah dimasa lalu sebagai referensi untuk mencegah dan menyelesaikan masalah yang terjadi dengan membuat keputusan yang efektif dan memperhitungkan dampak pada diri sendiri, sosial dan lingkungan.

d. Keterampilan menerapkan proses untuk gaya hidup dalam pembelajaran sejarah, adalah belajar mandiri dan belajar secara terus- menerus. Pembelajaran sejarah tersebut berguna untuk membentuk kohesi sosial untuk membangun hubungan yang baik antara siswa maupun siswa dengan masyarakat, pengelolaan konflik yang tepat, adaptasi terhadap perubahan masyarakat dan lingkungan. Sebagai contoh dalam pembelajaran sejarah mengenai revolusi prancis. Revolusi prancis terjadi salah satunya disebabkan oleh gaya hidup mewah ratu prancis hingga mendapatkan julukan madam of defisit karena berbanding terbalik dengan rakyatnya yang hidup sengsara. Belajar dari sejarah siswa dapat menghindari perilaku yang tidak diinginkan dan merugikan diri sendiri dan bahkan orang lain. 
e. Keterampilan menggunakan teknologi dalam pembelajaran sejarah, adalah kemampuan untuk memilih, dan menggunakan berbagai teknologi yang digunakan untuk pengembangan diri seperti komunikasi berbasis teknologi, kreatif, solutif, tepat dan sesuai. Keterampilan menggunakan teknologi dalam pembelajaran sejarah dapat dilakukan dengan memberikan siswa tugas untuk mengamati objek manusia purba yang berada di sangiran. Siswa mengumpulkan data dan bekerja kelompok secara online serta memberikan presentasi kepada kelas dengan menggunakan multimedia untuk memperoleh informasi. Pembagian kelompok dibagi secara acak dengan semua tingkat kompetensi sehingga dalam pelaksanaannya siswa didorong untuk melakukannya pemikiran dan penalaran kreatif berbasis teknologi.

3. Kendala-kendala Pendidikan Kecakapan Hidup dalam Pembelajaran Sejarah

Pergeseran pelaksanaan proses pembelajaran dari pendidikan langsung yang berubah menjadi pendidikan jarak jauh sebagai dampak penyebaran virus corona atau yang lebih dikenal dengan nama covid-19. Virus covid-19 penularannya dari manusia ke manusia dan infeksi parah pada manusia yang berasal dari kota Wuhan di Cina. (Chen N. dkk, 2020:1; Woo Chan JF. dkk, 2020: 1; Huang C. dkk, 2020: 1; Cao, Jianlei. dkk, 2020: 1; Paraskevis. D. dkk, 2019: 3).

Kebijakan work from home yang telah dilakukan menjadi kendala bagi guru dan siswa dalam pendidikan kecakapan hidup dalam pembelajaran sejarah. Pelaksanaan proses pembelajaran yang awalnya berada di sekolah berganti dengan sistem daring menimbulkan berbagai permasalahan. CNN Indonesia (2020) mengatakan bahwa kendala pada jaringan internet merupakan masalah utama yang hampir selalu terjadi selama proses pembelajaran daring. Penggunaan jaringan internet pada dasarnya membutuhkan biaya yang seringkali menjadi masalah dalam pelaksanaannya (Purwanto et al., 2020). Selain itu, dalam penelitian yang dilakukan oleh Permata \& Bhakti (2020: 31) mengatakan bahwa bahwa pembelajaran daring kurang efektif dalam pembelajaran. Pembelajaran yang kurang efektif akan mengurangi motivasi belajar siswa. Tinggi rendahnya motivasi belajar siswa sangat menentukan keaktifan dalam mengerjakan tugas yang diberikan (Sadirman, 2012: 84). Sehingga, siswa seringkali tidak siap menerima pembelajaran yang berlangsung dan kurang memperhaatikan selama proses belajar yang berlangsung akibat bermain media sosial sehingga cenderung memiliki masalah sosial dan akademik (Kwon et al., 2013; Siddiqui \& Singh, 2016).

4. Upaya mengatasi kendala Pendidikan Kecakapan Hidup dalam Pembelajaran Sejarah

Peran guru sejarah sangat penting untuk mengatasi kendala pendidikan kecakapan hidup yang mempersiapkan siswa menjadi cakap. Pembelajaran perlu dilengkapi, diintegrasikan dengan berbagai jenis dukungan tanpa adanya intervensi pihak lain melalui program revisi kurikulum atau pergantian kurikulum dan reformasi model pembelajaran yang sesuai di sekolah (Venezia \& Jaeger, 2013: 125). Penyusunan kurikulum dan reformasi model pembelajaran merdeka belajar memberikan angin segar bagi guru sejarah untuk mengatasi kendala pendidikan kecakapan hidup dalam pembelajaran sejarah. Pesce et al., (2016) mengevaluasi kemandirian gerak dalam penerapan kecakapan hidup dan menemukan pernyataan sementara yaitu "keterampilan hidup tidak hanya 
membantu dalam kesehatan fisik, tetapi juga peningkatan kesehatan mental". Kurikulum merdeka belajar merekomendasikan guru diberikan kebebasan untuk bergerak di sekitar ruangan, atau ruang memberikaan merangsang kreativitas. Demikian pula, Meyer dan Wurdinger (2016) menegaskan aktivitas keleluasaan guru menjadi sangat penting untuk mengukur kemampuan siswa dalam perolehan kecakapan hidup. Meyer mengatakan guru memiliki peran sebagai fasilitator dengan kebebasan geraknya menempatkan siswa di pusat pelajaran. Sehingga, siswa dapat mengembangkan kecakapan hidup mereka secara mandiri untuk memilih proyek yang relevan secara pribadi dan belajar memahami diri sendiri bersamaan dengan mengidentifikasi tujuan, sumber daya, dan merencanakan waktu dalam menyelesaikan tugas (Meyer \& Wurdinger, 2016: 16).

5. Apresiasi serta Persepsi Pendidikan Kecakapan Hidup dalam Pembelajaran Sejarah

Sobel (2012: 12) mengatakan kecakapan hidup dalam pembelajaran sejarah menganjurkan pengalaman belajar dunia nyata, membantu siswa berkembang menjadi lebih kuat dengan ikatan komunitas, meningkatkan apresiasi dan persepsi siswa, dan menciptakan komitmen yang tinggi untuk melayani sebagai warga negara yang aktif serta berjiwa nasionalisme. Apersepsi dan persepsi siswa terbentuk berdasarkan model, strategi, metode dan pendekatan pembelajaran yang digunakan oleh guru. Guru sejarah yang mampu menerapkan model, strategi, metode dan pendekatan pembelajaran yang tepat akan mampu mendapatkan apresiasi dan persepsi yang baik dari siswa. Hal ini diperkuat oleh pernyataan Swank dan Huber (2013) yang menyatakan bahwa keterlibatan (guru) secara tepat dalam upaya peningkatan sumber daya manusia (siswa) mampu memberikan kesempatan kepada siswa untuk mengapresiasi dan memberikan persepsi yang baik terhadap guru dan termotivasi untuk meningkatkan kecakapan hidupnya.

\section{SIMPULAN}

Permasalahan yang timbul dilingkungan siswa sekolah menengah atas di masa pandemi dapat diatasi dengan peningkatan pendidikan kecakapan hidup khususnya dalam pembelajaran sejarah. Langkah penerapan pendidikan kecakapan hidup dalam pembelajaran sejarah diuraikan menjadi lima bagian, yaitu (1) perencanaan yang dilakukan untuk mencegah berbagai tantangan kecakapan hidup yang dihadapi siswa seperti merokok, alkohol, penggunaan narkoba, pelecehan seksual, putus sekolah dan kehamilan diluar nikah, (2) pelaksanaan pendidikan kecakapan hidup dalam pembelajaran sejarah dapat dilakukan dengan penguasaan 5 keterampilan (komunikasi, berpikir, memecahkan masalah, menerapkan proses untuk gaya hidup dan menggunakan teknologi), (3) kendala-kendala pendidikan kecakapap hidup saat ini adalah jaringan internet, kurang efektifnya pembelajaran daring, motivasi belajar rendah dan kesiapan belajar siswa rendah (4) upaya mengatasi kendala dengan memberikan guru kebebasan bergerak untuk menempatkan siswa di pusat pelajaran. Sehingga, siswa dapat mengembangkan kecakapan hidup mereka secara mandiri untuk memilih proyek yang relevan secara pribadi dan belajar memahami diri sendiri bersamaan dengan mengidentifikasi tujuan, sumber daya, dan merencanakan waktu dalam menyelesaikan tugas dan (5) apresiasi serta persepsi peserta didik, guru sejarah yang mampu menerapkan model, strategi, metode dan pendekatan pembelajaran yang tepat akan mampu memperoleh apresiasi dan persepsi yang baik dari siswa. Sehingga, siswa semakin termotivasi untuk meningkatkan kecakapan hidupnya. 


\section{DAFTAR PUSTAKA}

Botvin, G. J., Griffin, K. W., Diaz, T., \& Ifill-Williams, M. (2001). Drug abuse prevention among minority adolescents: Posttest and one-year follow-up of a school-based preventive intervention. Prevention Science, 2(1), 1-13. doi:10.1023/a:1010025311161.

Budoya, Christian M. Kissaka, Mussa M. \& Mtebe, Joel S. (2019). Towards Developing Interactive Content for Enhancing Life Skills Education in Tanzania: Possibilities and Pitfalls. Published by Springer Nature Switzerland AG 2019. P. Nielsen and H. C. Kimaro (Eds.): ICT4D 2019, IFIP AICT 552, pp. 374-385. https://doi.org/10.1007/978-3-030-19115-3_31.

Campbell-Heider, N., Tuttle, J., \& Knapp, T. R. (2009). The effect of positive adolescent life skills training on long term outcomes for high-risk teens. Journal of Addictions Nursing, 20(1), 6-15. doi: 10.1080/10884600802693165.

Cao, J., Hu, X., Cheng, W., Yu, L., Tu, W.-J., \& Liu, Q. (2020). Clinical features and shortterm outcomes of 18 patients with corona virus disease 2019 in intensive care unit. Intensive Care Medicine. doi:10.1007/s00134-020-05987-7.

Chen N. dkk. (2020). Epidemiological and clinical characteristics of 99 cases of 2019 novel coronavirus pneumonia in Wuhan, China: a descriptive study. https://doi.org/10.1016/S0140-6736(20)30211-7.

CNNIndonesia. (2020). 4 Aplikasi Video Conference yang Irit dan Boros Data. 21 September 2020. https://www.cnnindonesia.com/teknologi/20200330191529-185488422/4 aplikasi video conference-yang-irit-dan-boros-data.

Creswell, Jhon W. (2016). Research Design Pendekatan Kualitatif, Kuantitatif, dan. Mixed. Yogyakarta: Pustaka Pelajar.

Danish, S., Forneris, T., Hodge, K., \& Heke, I. (2004). Enhancing youth development through sport. World Leisure Journal, 46(3), 38-49. https://doi.org/10.1080/04419057.2004. 9674365.

Duff, C., McPherson, A. C., King, G., \& Kingsnorth, S. (2019). Deconstructing residential immersive life skills programming through a pedagogical lens: mechanisms that can facilitate learning for youth with disabilities. Journal of Research in Special Educational Needs. doi:10.1111/1471-3802.12470.

Venezia, A., \& Jaeger, L. (2013). Transitions from High School to College. The Future of Children, 23(1), 117-136. https://doi.org/10.1353/foc.2013.0004.

Garrote, A. (2017). The relationship between social participation and social skills of pupils with an intellectual disability: A study in inclusive classrooms. Frontline Learning Research: An Official Journal of EARLI, 5(1), 1-15. https://doi.org/10.14786/flr.v5i1.266.

Givaudan, M., Leenen, I., Van De Vijver, F. J. R., Poortinga, Y. H., \& Pick, S. (2008). Longitudinal study of a school based HIVIAIDS early prevention program for Mexican Adolescents. Psychology, Health \& Medicine, 13(1), 98-110. doi:10.1080/13548500701295256. 
Huang, C., Wang, Y., Li, X., Ren, L., Zhao, J., Hu, Y., ... Cao, B. (2020). Clinical features of patients infected with 2019 novel coronavirus in Wuhan, China. The Lancet. doi:10.1016/s0140-6736(20)30183-5.

Jedaman, Pornchai. Kinboon, Nittayaporn. Suksup, Chareon. \& Kinboon, Wutcharapong. (2018). The development of learning competency and skills for the 21 st century to integrate "TPCK" of world life with local environment in students grade 11. Citation: AIP Conference Proceedings 1923, 030022 (2018); doi:10.1063/1.5019513.

Kansaart, Preecha. Suikraduang, Arun. \& Panya, Piyatida. (2018). Using the learning management evaluation model for advancing to life skills of lower secondary students in the 21st century. Citation: AIP Conference Proceedings 1923, 030064; doi:10.1063/1.5019555.

Kwon, M., Lee, J. Y., Won, W. Y., Park, J. W., Min, J. A., Hahn, C., ... Kim, D. J. (2013). Development and Validation of a Smartphone Addiction Scale (SAS). PLoS ONE. https://doi.org/10.1371/journal.pone.0056936.

MacKillop, J., Ryabchenko, K. A., \& Lisman, S. A. (2006). Life skills training outcomes and potential mechanisms in a community implementation: $A$ preliminary investigation. Substance Use \& Misuse, 41(14), 1921-1935. doi:10.1080/10826080601025862.

Martin, K., Nelson, J., \& Lynch, S. (2013). Effectiveness of school- based life-skills and alcohol education programmes: A review of the literature.

Menrath, I., Mueller-Godeffroy, E., Pruessmann, C., Ravens-Sieberer, U., Ottova, V., Pruessmann, M., Thyen, U. (2012). Evaluation of school-based life skills programmes in a high-risk sample: A controlled longitudinal multi-centre study. Journal of Public Health, 20(2), 159-170. doi:10.1007/s10389-011-0468-5.

Meyer, K., \& Wurdinger, S. (2016). Students' Perceptions of Life Skill Development in Project-Based learning Schools. Journal of Educational Issues, 2(1), 1-24. https://doi.org/10.5296/jei.v2i1.8933.

McPherson, A. C., King, G., Rudzik, A., Kingsnorth, S., Gorter, J. W. \& Ontario Independence Program Research (OIPR) team (2016) 'Optimizing life success through residential immersive life skills programs for youth with disabilities: study protocol of a mixedmethods, prospective, comparative cohort study.'BMC Pediatrics, 16 (1), pp. 153.

Nasheeda, Aishath. Haslinda Binti Abdullah. Krauss, Steven Eric \& Nobaya Binti Ahmed. A narrative systematic review of life skills education: effectiveness, research gaps and priorities. International Journal of Adolescence and Youth, DOI:10.1080/02673843.2018.1479278.

Paraskevis, D., Kostaki, E. G., Magiorkinis, G., Panayiotakopoulos, G., Sourvinos, G., \& Tsiodras, S. (2020). Full-genome evolutionary analysis of the novel corona virus (2019-nCoV) rejects the hypothesis of emergence as a result of a recent recombination event. Infection, Genetics and Evolution, 104212. doi:10.1016/j.meegid.2020.104212. 
Permata, Andira \& Bhakti, Yoga B. (2020). Keefektifan Virtual Class dengan Google Classroom dalam Pembelajaran Fisika Dimasa Pandemic Covid-19. JIPFRI, Vol. 4 No. 1 Halaman: 27 - 33 Juli 2020. https://doi.org/10.30599/jipfri.v4i1.669.

Pesce, C., Marchetti, R., Forte, R., Crova, C., Scatigna, M., Goudas, M., \& Danish, S. J. (2016). Youth life skills training: Exploring outcomes and mediating mechanisms of a group randomized trial in physical education. Sport, Exercise, and Performance Psychology, 5(3), 232-246. https://doi.org/10.1037/spy0000060.

Prajapati, R., Sharma, B., \& Sharma, D., (2017). Significance of Like Skills Education. Contemporary Issues in Education Research, 10(1), 1-6. Retrieved 18 September 2020, from http://files.eric.ed.gov.esearch.ut.edu/fulltext/EJ1126842.pdf.

Purwanto, A., Pramono, R., Asbari, M., Santoso, P. B., Wijayanti, L. M., Hyun, C. C., \& Putri, R. S. (2020). Studi Eksploratif Dampak Pandemi COVID-19 Terhadap Proses Pembelajaran Online di Sekolah Dasar. Journal of Education, Psychology, and Counseling, 2, 1-12.

Ramey, L. (1984). A Life Skills Program for Incarcerated Offenders: Origin and Development. Journal of Correctional Education, 35(2), 50-53. Retrieved 21 September 2020, from http://www.jstor.org. esearch.ut.edu/stable/41971284.

Rateau, R. J., Kaufman, E. K., \& Cletzer, D. A. (2015). Innovative Classroom Strategies That Prepare College Graduates for Workplace Success. Journal of Agricultural Education, 56(3), 52-68. https://doi.org/10.5032/jae.2015.03052.

Sadirman. (2012). Interaksi dan Motivasi Belajar Mengajar. Jakarta: PT Raja Grafindo Persada.

Swank, J. M., \& Huber, P. (2013). Employment Preparation and Life Skill Development Initiatives for High School Students with Emotional and Behavioral Disabilities. The Professional Counselor, 3(2), 73-81. https://doi.org/10.15241/jms.3.2.73.

Sobel, D. (2004). Place-Based Education: Connection Classroom and Community. Nature and Listening. Retrieved 21 September 2020, from http://www.antiochne.edu/wpcontent/ uploads/2012/08/pbexcerpt.pdf.

Siddiqui, S., \& Singh, T. (2016). Social Media its Impact with Positive and Negative Aspects. International Journal of Computer Applications Technology and Research. https://doi.org/10.7753/ijcatr0502.1006.

Trilling and Fadel. (2009). 21st century skills: learning for life in our times. USA: Jossey Bass.

United Nations Children's Fund. (2015). The Investment Case for Education and Equity. UNICEF Education Section, New York, NY.

Woo Chan JF. dkk. (2020). A familial cluster of pneumonia associated with the 2019 novel coronavirus indicating person-to-person transmission: a study of a family cluster. https://doi.org/10.1016/S0140-6736(20)30154-9.

WHO. (1993). Life skills education in schools. WHO/MNH/PSF/93.7A.Rev.2. 
Yadav, P., \& lqbal, N. (2009). Impact of Life Skill Training on Self-esteem, Adjustment and Empathyamong Adolescents. Journal of the Indian Academy of Applied Psychology, 35(Special Issue), 61-70. Retrieved 22 September 2020, from http://medind.nic.in/jak/t09/s1/jakt09s1p61. 